\title{
Liberating Pathologization? The Historical Background of the 1961 Decriminalization of Homosexuality in Hungary*
}

Judit Takács,

Centre for Social Sciences, Hungarian Academy of Sciences Centre of Excellence; KWI Essen

takacs.judit@tk.bu

Tamás P. Tóth

Centre for Social Sciences, Hungarian Academy of Sciences Centre of Excellence;

Artist \& Researcher in Residence Guiniguada, Canary Islands

p.toth.tamas@tk..bu

Analyzing the principles, considerations, and official explanations underpinning the (de)criminalization of sexual relations between same-sex partners can highlight that around the mid-twentieth century medicalizing references were used in legal and societal judgments on same-sex intimacy in Hungary (and elsewhere). In this study, we want to illustrate the medicalization process of social issues that otherwise seem difficult to "solve" (i.e., these issues, in this case, were put within a psycho-medical ambit) by focusing on a twentieth-century historical example from Hungary. The background of the decriminalization of consensual sexual acts between adult men in the 1961 Hungarian Penal Code will be explored in detail using previously unknown original archival material from 1958. This article will introduce the changes proposed by the Neurology Committee of the Health Science Council (HSC; Egészségügyi Tudományos Tanács) in 1958 leading to the HSC's unanimous support for a proposal to decriminalize "unnatural fornication" between consenting adults and to the actual decriminalization of homosexuality (i.e., decriminalization of consensual sexual acts between adult men) in 1961. The empirical foundation of the present study includes archival records from the National Archives of Hungary and other primary sources.

Keywords: homosexuality, (de)criminalization, social history, state-socialism, National Archives, Penal Code, Neurology Committee of the Health Science Council

\section{Introduction}

It would be pointless to look for homosexuality anywhere in the criminal codes that were in force in Hungary. This term, which was coined, together with the term "heterosexuality," by Károly Kertbeny, ${ }^{1}$ an Austrian-Hungarian writer

\footnotetext{
* The authors gratefully thank Johann Karl Kirchknopf for his insightful comments on a previous version of the manuscript.

1 Takács, "The Double Life of Kertbeny."
} 
and journalist in the late 1860s, does not appear anywhere in these codes. In the second half of the nineteenth century, homosexual practices began to be punishable under the heading of "unnatural fornication" or literally "perversion against nature" (természet elleni fajtalanság) in the chapter on crimes and offences against sexual morality in Article V of the Criminal Code of 1878, the first Hungarian-language criminal code of the Hungarian Kingdom, which was drafted by Károly Csemegi, State Secretary of Justice of the Government of Kálmán Tisza. ${ }^{2}$ Here paragraphs 241 and 242 drew a distinction between the offences of unnatural fornication committed between men or by a person to an animal on the one hand and the more harshly punished crime of unnatural fornication that involved violence or the threat of violence. ${ }^{3}$

The most important antecedent to the Csemegi Code of 1878 is the work of Tivadar Pauler, who served as Minister of Justice between 1872 and 1875, on criminal law studies, which was first published in 1864, just a few years before the Austro-Hungarian Compromise of 1867. Here, in paragraphs 396-400, unnatural fornication, i.e., crimen sodomiae or the crime of sodomy, is defined as "sexual intercourse contrary to the natural order," which should be punished because of its "gross violation of moral sentiment, irrational ignorance of the natural order, demeaning of human dignity, and the withering and harmful effects on one's intellectual properties and physical health."4 Pauler's approach reflects a potential Austrian influence in terms of the offenders' gender, as according to the Austrian penal code sodomy could be committed not only by men but also by women (the "Tribadie" provision of the Austrian penal code was introduced in 1852 and remained in effect until 1971). Pauler distinguished between three main forms of unnatural fornication: it was defined not only as sexual intercourse conducted with an animal or with a same-sex partner but also as a sexual intercourse conducted with a different-sex partner in an unnatural way. At the same time, "serious violations of morality and prudency" within family life were considered only petty offences. ${ }^{6}$

The Csemegi Code, which remained in effect for more than 80 years, differed in two major points from the legal text proposed by Pauler (1870): its prohibition of unnatural fornication affected neither different-sex partners

2 For more details about this historical period in Hungary, see Fónagy, "The Age of Dualism."

3 Magyar Törvénytár.

4 Pauler, Büntetójogtan, 121.

5 Kirchknopf, "Ausmaß und Intensität"; Kirchknopf, Fornication against nature.

6 Pauler, Büntetójjogtan, 126. 
nor same-sex female partners. However, the precise scope of what exactly constituted unnatural fornication was hard to determine, as was shown in the penal code interpretations by Károly Illés Edvi, a skilled prosecutor who took part in the writing of the Csemegi Code. In his view "in a broad sense it refers to the unnatural satisfaction of any kind of sexual lust," including "selfcontamination and the use of inanimate objects [...] these cases, however, have been ignored even by the old legal doctrine and legislation that distinguished three main forms of what could be interpreted as sodomy in a strict sense: sexual intercourse conducted with a) an animal [...] b) a person of the same sex [...] and c) a person of different sex in an unnatural manner. The case under b) included various unnatural activities that can be conducted among women (lesbian love), too. The present law completely ignores the latter case, which also divided the opinion of the old criminalists, and renders unnatural fornication between different sex partners punishable only as far as it was covered by $₫ 233$ [of the Penal Code on sexual assault]."7

Even a quarter of a century later, several points remained contentious regarding the exact scope of unnatural fornication. For example, Pál Angyal, a criminal lawyer who specialized in issues concerning sexual morality and a leading figure of the Hungarian lawyers' society in the early twentieth century, outlined the desirable changes regarding the future criminal policy in the following way:

de lege feranda [...] 1. onanism should remain unpunished, 2. punishment of fornication between men should be sustained [...] 3. unnatural fornication between women should be criminalized 4. punishment of bestiality should be sustained only because it is morally undesirable to delete an existing ban [...] 5. necrophilia [should be punished] only in the case of causing scandal (possibly under the heading of desecrating a corpse or crime against religion) 6. criminalizing unnatural fornication conducted between different sex persons is unreasonable (except for the cases covered by 233 \ of the Criminal Code) because these acts quite often precede or follow normal intercourse [...] but fornication conducted by a woman with an adolescent boy should be punished $[\ldots]$ 7. seduction to commit homosexual acts or offering these services, however, should be rendered punishable. ${ }^{8}$

In Angyal's argument, it is striking to see the double standard applied to nonreproductive sexual practices in terms of the sex of the alleged fornicators: if the

7 Edvi, A magyar büntetötörvénykönyv magyarázata, 294-95.

8 Angyal, Sžmérem elleni büntettek, 78. 
acts were conducted by same-sex partners, they were seen as having the potential to cause social harm. At the same time, non-reproductive sexual practices conducted by different-sex partners were depicted as belonging to a broader repertoire of sexual activities or sexual play (such as foreplay), which in the worst case could be interpreted at an interpersonal level as morally wrong. This is why Angyal would have preferred to introduce the criminalization of samesex "fornication" between women in addition to maintaining the prohibition of same-sex "fornication" between men, while avoiding the criminalization of fornication between different-sex partners.

\section{Criminalization: A Contested Issue}

Criminalization of consensual sexual practices between same-sex individuals, especially between adult men, has been a contested issue in Central Europe since at least the second half of the nineteenth century. There had been no discussion of legalization up to this point in time, because for centuries, any queer act transgressing the ostensibly God-given authority of the Church and the monarch had been covered by the broad category of sodomy or unnatural fornication. In the period before the concepts of homosexuality and heterosexuality had been invented, sodomy was understood as an act that could be committed by anyone, regardless of that person's sex or the sex of the person with whom the act was committed. ${ }^{9}$

In the 1860s, the German writer and jurist Karl Heinrich Ulrichs argued for decriminalization in a biologically essentializing manner: in his view, urnings, i.e., men who loved men, characterized by a certain degree of femininity of the soul, made up a third sex. ${ }^{10}$ Thus, according to Ulrichs, adult men in a consensual sexual relationship with each other should not be prosecuted for acting upon their nature-given innate drive. Ulrichs and Kertbeny had known each other since 1864: in that year, Kertbeny's book on the Austrian American writer Charles Sealsfield was published, in which Ulrichs found "the first mention of my theory in print." Ulrichs considered Kertbeny one of his first "comrades." 11 They regularly corresponded until 1868 , when their disagreement about the practicality of their urning/homosexuality concepts in the argument for decriminalization

9 As Foucault points out, "The sodomite had been a temporary aberration; the homosexual was now a species." Foucault, The History of Sexuality, 42.

10 Kennedy, Ulrichs, 63-64.

11 Ibid.,189. 
reached its peak. One of their points of dispute concerned the issue of gender inversion, which Ulrichs presented as an all-encompassing explanation for samesex desire: in his view, the "truly feminine nature" of urnings would render them biologically more like women than men. In contrast, Kertbeny, while he also observed that homosexual men "like to socialize with women, with whom they behave not as men, but rather as though they were women, loving gossip, domestic work, and concerns, and devoted to each other like sisters," did not see gender inversion as an essential feature of homosexuality. ${ }^{12}$

While at first, they both seemed to agree about the necessity of looking for the scientific proof of the inborn nature of homosexuality, Kertbeny later saw this as a useless argument, because of its limited power to persuade legislators. In fact, the first known appearance of the new terms homosexual and heterosexual can be traced to the private letter written by Kertbeny to Ulrichs in 1868, in which Kertbeny put forward a classic liberal argument of non-intervention by the modern state in the intimate lives of its citizens:

To prove innateness [...] is a dangerous double-edged weapon. Let this riddle of nature be very interesting from the anthropological point of view. Legislation is not concerned whether this inclination is innate or not, legislation is only interested in the personal and social dangers associated with it [...] Therefore, we would not win anything by proving innateness beyond a shadow of doubt. Instead, we should convince our opponents — with precisely the same legal notions used by them — that they do not have anything at all to do with this inclination, be it innate or intentional, since the state does not have the right to intervene in anything that occurs between two consenting persons older than fourteen, which does not affect the public sphere, nor the rights of a third party. ${ }^{13}$

In 1869, however, in an anonymously published open letter to the Prussian Minister of Justice, Kertbeny called for the elimination of the Prussian penal code criminalizing same-sex sexual activities by emphasizing that "homosexual impulses are not optional [...] but rather congenital," which "excludes the thought that homosexuals in time, can be made to join the ranks of the majority, which has been born with the stronger drive, normalsexualism." "This was the first time that the word homosexual, created from the Greek bomo ("same")

12 Tobin, Peripheral Desires, 125.

13 Translated by the author from Kertbeny, Levéltöredék. For the English translation of the full document, see Pretsell, The Correspondence of Karl Heinrich Ulrichs, 199-205.

14 Kertbeny, "An Open Letter," 72. 
and the Latin sexus ("sex"), was publicly used. In this political pamphlet, which was reprinted in 1905 by Magnus Hirschfeld as "one of the best works on the homosexual problem," 15 Kertbeny tried to merge Ulrichs' innate drive argument with that of privacy:

It is obvious to thinkers educated in anthropology that those who are constrained by such [homosexual] drives either meet with individuals of their own nature, and, therefore, there is absolutely nothing at all to justify objecting to such reciprocal inclinations, because both are lacking normalsexuality by nature, and, therefore, it would be asking too much of them to live their whole life long in absolute chastity, and to submit their existence to a penalty because, through no fault of their own, nature organized them with this very constraint. Or however, such homosexuals turn their inclinations to normalsexuals; and if the modern constitutional state makes a concession to the latter, in principle, in all cases in which no rights of others are injured by it, that they will be allowed to do with their bodies as they please, then it will not be necessary to differentiate between acts, whether the same are natural or would-be unnatural, if they are practiced by the opposite sex or the same sex. ${ }^{16}$

Despite the opposition of Ulrichs, Kertbeny and others, including even the Royal Prussian Scientific Commission for Medical Affairs, in 1871, after the first German unification, the Prussian anti-sodomy statute was introduced as Paragraph 175 into the new German Imperial Criminal Code. ${ }^{17}$ The introduction of Paragraph 175 facilitated the continuation of criminal prosecution in some parts of Germany, such as Prussia, while it meant the re-criminalization of consensual homosexual acts in other parts of Germany, including Bavaria, Württemberg, Baden, Hanover, and Brunswick.

At the very end of the nineteenth century, decriminalization arguments surfaced in Hungary, too. For instance, in 1894 András Eördögh, a Hungarian lawyer, challenged the article on unnatural fornication by pointing out that it is nonsense to outlaw acts that cannot be prevented and take place mostly in publicly concealed ways, including "the act of consensual sodomy conducted by adults in secrecy that makes the act inherently unpreventable."18

15 Kennedy, Ulrichs, 186.

16 Kertbeny, "An Open Letter," 72.

17 Beachy, "The German Invention of Homosexuality," 804.

18 Eördögh, "A büntetőtörvény 241. 〔-áról," 4. 
In the early years of the twentieth century, Hungarian abolitionist lawyers were of the opinion that unnatural fornication should not be rendered punishable by law because it was increasingly seen as a medical rather than legal issue. Instead of legal expert involvement, abolitionists argued for shifting the social responsibility to medical experts, as only physicians would be able (they thought) to distinguish between the symptoms of an inborn mental illness and illicit intemperance. For instance, in 1905, Péter Reich, an abolitionist lawyer, argued for "deleting pederasty from all modern penal codes" on the basis of the "fully elucidated medical notions about pederasty deriving from a degenerate mental disposition" and the recognition that "punishment does not contribute to the improvement of the pederasts' condition: they cannot resist their inclination no matter how long they would be imprisoned [...consequently] deterrence is out of the question."19 Applying a "cure instead of imprisonment"-framework potentially involved prescribing social isolation that practically meant that the person had to be locked up in specialized medical or mental institutions, an increasingly popular view across Europe (see, for instance, the case of Oscar Wilde). ${ }^{20}$

It is not difficult to see that abolitionist arguments, common in the medical literature of the period, ${ }^{21}$ were far from recognizing individual rights and liberties or reflecting the social acceptability of same-sex attractionbased relationships. Rather, their main point was about letting these forms of behavior and relationships, which were typically conducted secretively due to their stigmatization by society, remain concealed so that the chances of social exposure would be minimized, while through criminalization, these cases could easily attract more widespread attention, for instance, by media representations focusing on the "scandalous" details of suspects' lives. While Hungarian abolitionists did not achieve their goals for more than half a century, some of their arguments resurfaced at the 1958 meeting of the Neurology Committee, which will be discussed later in detail.

19 It should be noted that Reich used Ulrichs' urning terminology in his text, in which he refers to urnings as being characterized by (gender) inversion and thus, from their perspective, driven by their feminine inclination, homosexuality might seem to be a natural state of affairs. Reich, "A természet elleni fajtalanság büntethetőségéről," 90 .

20 Janes, "Oscar Wilde."

21 Borgos, Nemek között. 


\section{Changing Decriminalization Landscapes in Twentieth-Century Central and Eastern Europe}

To appraise the Hungarian developments in a regional context, we will give a quick overview of the decriminalization landscapes in the former Eastern Bloc countries, where we can see a diversity of approaches to (de)criminalization of same-sex sexual practices. For example, after the reintroduction of a comprehensive anti-homosexuality legislation in 2013, prohibiting the "propaganda of non-traditional sexual relations" 22 at the Russian state-level it is perhaps hard to believe that there was a Russian sexual revolution in the early twentieth century. ${ }^{23}$ The first Soviet-Russian criminal code of 1922 abolished the sodomy laws of tsarist Russia. Indeed, the very first Penal Code proposal of January 1918, only months after the October Revolution, no longer contained the old sodomy legislation, and it set the age of consent for both homosexual and heterosexual acts at 14 years of age. ${ }^{24}$ The Soviet-Russian sexual revolutionary period and the transitional legalization of same-sex relationships as part of it came to an end with Stalin's rise to power. The 1934 Soviet Criminal Code recriminalized consensual sexual acts between same-sex adults, and redecriminalization took place only in 1993. The temporary decriminalization of homosexuality between 1922 and $1933^{25}$ reflected the rejection of moral standards based on religious belief, ${ }^{26}$ and the Bolsheviks' transient position about the criminalization of homosexuality being a bourgeois relic. Stalinism, by contrast, "relied on an intolerant and negative view of sex," and "for the sake of both the nation and the Communist Party," ${ }^{27}$ Stalinism demanded marital and family stability from its citizens. Framing of homosexuality as detrimental to the nation was also a familiar argument used in Nazi Germany about sexual life to serve the goal of preserving the race and the nation, and homosexuality was heavily condemned due to its "asocial" character and its "adverse effects on the German birth rate." ${ }^{28}$ We can also observe similarities in the treatment of communists and homosexuals during McCarthyism in the US in the 1950s,

\footnotetext{
22 Kondakov, "Rethinking of the sexual citizenship," 402.

23 Stella, Lesbian Lives in Soviet and post-Soviet Russia.

24 Healey, Homosexual Desire in Revolutionary Russia; Healey, "Homosexual Existence and Existing Socialism."

25 Healey, Homosexual Desire in Revolutionary Russia.

26 Hildebrant, "Routes to decriminalization."

27 Herzog, Sexuality in Europe, 100.

28 Pine, Nazi Family Policy, 122.
} 
comparable with state-socialist considerations of homosexuals being "unreliable elements," characterized by high levels of "blackmailability"29 and limited (reproductive) contributions to building state-socialism.

Poland took up a unique position in this regard, since in the period between the 1930s and the 1980s, it had "a more progressive legislation towards homosexuality than some Western Bloc countries." ${ }^{30}$ In fact, the Polish Penal Code, based on the French example (i.e., the Napoleonic Penal Code of 1810, based on the French Penal Code of 1791) never forbade sodomy. However, Russian, Prussian and/or Austrian criminal law was applied depending on the particular jurisdiction of the various Polish territories. Today it might sound surprising, but, disregarding the Soviet-Russian criminal code of 1922, the Polish criminal law of 1932 was the first in Europe to decriminalize homosexuality in the twentieth century. ${ }^{31}$

Romania can also be considered an exceptional case. Here, criminalization of consensual homosexual acts for both men and women was introduced for the first time, coincidentally, just two years after homosexuality was re-criminalized by Stalin in the Soviet Union. The 1936 Romanian Penal Code came into effect during the chaotic years preceding World War II, when the Kingdom of Romania was more aligned with Nazi Germany than Soviet Russia. ${ }^{32}$ New Romanian legislation entered into force in 1996, criminalizing homosexual acts performed in public places or in a scandalous manner; in addition, the legal regulations opposing "homosexual propaganda" also restricted gay and lesbian people's freedom of expression and association: ${ }^{33}$ the infamous "section 200" (i.e., Article 200 of the 1968 Romanian Penal Code, criminalizing public manifestations of homosexuality) was abolished only in 2001.

The notion that homosexuality is a pathological phenomenon and therefore ought not to be punishable by law was essential to the state-socialist governments' decisions to legalize consensual homosexual sex in Czechoslovakia and Hungary in 1961, but they each relied on different medicalized approaches. Sexology research flourished after the opening of a Czech sexology institute by Josef Hynie in 1921 in Prague, which remained in operation during the

29 Moss, "The Underground Closet," 230.

30 Szulc, Transnational Homosexuals in Communist Poland, 91.

31 It should be noted that in quite a few European countries, homosexual activities were decriminalized already in the eighteenth and the nineteenth centuries, including France (1791), Belgium and Luxembourg (1795), the Netherlands (1811), Spain (1822), and Italy (1890).

32 HRW, Public Scandals.

33 Long, "Gay and lesbian movements in Eastern Europe." 
state-socialist period. Hynie and his colleagues applied medical rather than criminal approaches to sexual deviations; regarding the sexological treatment of homosexuality, Czech physician Kurt Freund played an especially important role. ${ }^{34}$ After his failed aversion therapy experiments of the 1950s, Freund came to the conclusion that homosexuality is not "curable" with medication or any other form of therapy, such as electroshocks. He became increasingly convinced that homosexuality ought to be decriminalized, and thus he came to feel that counseling self-acceptance is advisable. Freund admitted that he was not happy about his "therapeutic experiment which, if it has 'helped' at all, has helped clients enter into marriages that later became unbearable." ${ }^{35}$ Freund took part in organizing a legal-psychiatric seminar, where psychiatrists, sexologists, legal experts, and representatives from the police drafted a consensual proposal about the unnecessity of the prohibition of homosexual acts, which contributed to the renewal of the Czechoslovak Penal Code in $1961 .^{36}$ The initial draft of the new Czechoslovak Penal Code in March 1961 maintained the general penalization provision for homosexual acts, but its final form criminalized only homosexual acts between adults and minors (youths under eighteen), prostitution, or sexual acts performed under circumstances regarded as a public scandal. ${ }^{37}$ The law came into effect on January 1,1962, half a year earlier than the Hungarian provision, and an equal age of consent at the age of 15 was introduced as early as 1990, much sooner than it was in Hungary.

In 1968, Bulgaria and the German Democratic Republic (GDR) decriminalized male same-sex sexual activity on the grounds that homosexuality is a medical matter rather than a police matter. ${ }^{38}$ However, Bulgaria retained laws against acts that "cause public scandal or entice others to perversity," 39 and Bulgaria set a higher age of consent for homosexual acts than it did for heterosexual sex (18 and 14, respectively), while in the GDR the prohibition of consensual homosexual acts was removed only between adult men, although this prohibition had not been enforced in practice since the end of the 1950s. ${ }^{40}$

In the same year, Yugoslav legal experts argued against repressive measures for dealing with "deviant sexual behavior of two consenting adults" and defined

\footnotetext{
34 Davison, "Cold War Pavlov"; Sokolova, "State approaches to homosexuality."

35 Freund, "Should homosexuality," 239.

36 Sokolova, "State approaches to homosexuality"; Davison, "Cold War Pavlov."

37 Seidl, "Decriminalization of Homosexual Acts."

38 McLellan, "Love in the Time of Communism."

39 Torra, "Gay rights after the Iron Curtain," 75.

40 McLellan, "Glad to Be Gay Behind the Wall."
} 
homosexuality as a "less dangerous social phenomenon" in an official report. ${ }^{41}$ This led to the first Yugoslav decriminalization wave in the Socialist Republics of Croatia, Slovenia, and Montenegro and in the Socialist Autonomous Province of Vojvodina (in the northern part of Serbia, with a considerable Hungarian ethnic minority) in 1977. In Slovenia and Montenegro, the age of consent remained 14 years of age for all, while in Croatia and Vojvodina the age of consent for homosexual acts was set at $18 .^{42}$ A second wave of decriminalization took place only after the dissolution of Yugoslavia in the former Yugoslavian republics that had not repealed their relevant laws earlier, starting with Serbia in 1994.

As the Soviet Union maintained criminalization from the 1930 s until its collapse in 1990, decriminalization could start only in its successor states, including Ukraine in 1991, Estonia and Latvia in 1992, Lithuania and Russia in 1993, Belarus in 1994; followed by Albania and Moldova in 1995, and Romania in $1996 .{ }^{43}$

The diversity in the timing and forms of decriminalization (and in some cases, re-criminalization) of homosexual practices challenges interpretations of the region as a homogeneous bloc. Several factors contributed to the heterogeneity we found, including varying cultural, legal, and religious traditions, criminalizing and/or pathologizing approaches, as well as democratic and economic conditions. In the discussion below, we offer a closer look at the specific details of the 1961 decriminalization in Hungary.

\section{Legalizing Same-sex Sexual Acts between Consenting Adults in Hungary}

The "decriminalization of homosexuality," as the legalization of same-sex sexual acts between consenting adults has often been referred to, was not realized in Hungary until Act V of 1961 of the Hungarian Penal Code of the People's Republic of Hungary came into effect. In the state-socialist criminal code, which entered into force on July 1, 1962, "unnatural fornication" was discussed under Paragraphs 278-279, alongside other crimes against sexual morality. One of the main novelties of this new legislation was what was left out of it: in particular, the "general, i.e., completely unrestricted, penalization of unnatural fornication." 44 With the introduction of this legislation, consensual homosexual

41 Takács, Kuhar, and P. Tóth, "Unnatural Fornication Cases under State-Socialism," 1949.

42 Torra, "Gay rights after the Iron Curtain."

43 Hildebrant, "Routes to decriminalization."

44 OGyI, 270. 
activity between adult men ceased to be criminalized in Hungary, as did bestiality. Additionally, the definition of potential perpetrators and victims also changed: gender equality was introduced in the sense that from this point on, both men and women could be prosecuted equally for "unnatural fornication." According to the official reasoning justifying the bill presented to the Hungarian Parliament on December 15, 1961,

$[\mathrm{H}]$ omosexuality is either an inborn sexual perversity rooted in a developmental disorder or an acquired anomaly that develops mainly within neurotic people as a result of some sort of sexual impression during childhood, adolescence, or at a young age. According to medical observations, even in the case of acquired homosexuality or of those who wanted to free themselves (from homosexuality), the soundest therapy could hardly ever lead to the desired result. Homosexuality is a biological phenomenon and can therefore not be handled legally as a crime. Finally, in the course of its legal regulation, the practical point should be considered that criminalization of such behavior would provide a wide scope for blackmail. ${ }^{45}$

The medical(ized) definition of homosexuality that was used as a main reference point in introducing the new legislation offers one indication that, by 1961, the disease models of homosexuality had also reached Hungarian policymakers. While we cannot be sure exactly how this happened, we can certainly assume that it was the combined effect of several causes, including a wider sense of political relief at the end of the totalitarian Rákosi era (the historical period named after Mátyás Rákosi, the General Secretary of the Hungarian Communist Party between 1948 and 1956), followed by a process of modernization in family policy, ${ }^{46}$ starting with the liberalization of the previously very strict abortion regulation, and the gradual reinstating of psy-sciences, which had been practically banned during the Rákosi era. ${ }^{47}$

With the crystallization of psychology and psychiatry as sciences, several disease model variations, some promoting fixed biological determination, others emphasizing the inhibited development or trauma-drivenness of homosexuality, had become increasingly widespread since the late nineteenth and early twentieth

\footnotetext{
45 Ibid.

46 Szikra, Rat, and Inglot, Continuity and Change in Family Policies.

47 The Stalinist-style political repression of psy-sciences was reflected by the silencing and stigmatization of psychoanalysis as a "bourgeois pseudo-science." For a detailed overview of the state of psy-sciences under state-socialism in Hungary, see Kovai, Lélektan és politika.
} 
century in the Western world, ${ }^{48}$ and these ideas and models were adopted and adapted by Hungarian psy-scientists too. Medicalization in legal practice may have proven useful because it provided apologetic arguments to protect those found to be involved in illegal (homo)sexual acts from imprisonment. However, the long term effect of applying medicalized and often pathologizing models of homosexuality and other non-reproductive forms of sexuality was that essentialist interpretations of sexuality became so widely palatable and socially acceptable that attempts to get rid of them seem to have been largely unsuccessful, even today. ${ }^{49}$

The novelties of the Penal Code of 1961 that was in force between July 1962 and June 1979 included setting the age of consent for same-sex sexual relations at 20 . The main goal of this clause within Paragraph 279 was to protect the youth aged between 14 (as the age of consent for heterosexual relations) and 20 from "homosexualization" (i.e., becoming homosexual) since, at least according to the legislators' argument, this is "the age when the sexual drive, due to perverted experiences, can easily be skewed in a distorted direction." 50

Youth protection was one of the main goals of another clause of Paragraph 279 on unnatural fornication committed in a "scandalous manner" (though the definition of what could constitute a "scandal" was rather elusive), for which one could be sentenced to up to three years in prison in cases provoking "disgust, indignation, anger etc. in others." 51 Although the text of the law referred to "others" in the plural, according to the official legal interpretation, a crime had been committed even if the acts were witnessed by only one person who felt disgusted or offended. (This clause could be used as a reference, for instance, by police officers raiding a hotel room where a same-sex couple would have had a tryst in the $1960 \mathrm{~s}^{52}$ )

As has already been mentioned, the new Penal Code put gender equality into legal practice in the sense that homosexual acts conducted by women with a partner younger than 20 and/or in a scandalous manner were criminalized too, while homosexual acts between female partners had been beyond the scope of

48 For a detailed discussion on how psychoanalysts "queered" the scientific study of homosexuality in the German speaking world from the 1890s to the 1920s, see Lang and Sutton, "The Queer Cases of Psychoanalysis."

49 See also Borgos, "Homosexuality and psychiatry."

50 OGyI, 271.

51 Ibid.

52 In an interview conducted by the authors in 2015, one of the retired police officer interviewees spoke of these police procedures being used against homosexual men in particular. 
the previous criminal codes. As an additional novelty, all children under the age of 14 could become a victim of sexual assault, not only "decent maidens," 53 while previously the idea of protecting young boys from sexual assault or women perpetrating sexual assault had not even occurred to legislators.

The new Hungarian Penal Code of 1961 introduced many significant changes, among which "decriminalizing homosexuality" is a remarkable one, even though it clearly held same-sex sexual relationships to a different set of standards than heterosexual relationships and provided legal means for the authorities to press charges against people involved in homosexual acts. (For instance, the age of consent for same-sex relationships, irrespective of gender, was set at 20 , considerably higher than 14 , the age of consent for heterosexual relationships. In 1978, the age of consent for homosexual relationships was reduced to 18, but it was not until 2002 that an equal age of consent was set at 14 for all consensual sexual relations. $)^{54}$ However, the question of what led to this turn of events in 1961 remains at least partly open.

\section{Psychiatrists in Action}

The notion that homosexuality is a pathological phenomenon was essential to the legalization of consensual homosexual sex in Hungary: it was reflected not only in the official reasoning of the bill but also in reports reciting such arguments..$^{55}$ However, though no mention of the following fact is found in the earlier secondary literature on the subject, the political decision about decriminalization was informed by prominent Hungarian psychiatrists' expert opinion. Based on previously undocumented archival records found in the National Archives of Hungary, it is clear now that, in 1958, the Neurology Committee of the Health Science Council (HSC; Egésaségügyi Tudományos Tanács) provided unanimous support for a proposal to legalize same-sex sexual acts between consenting adults and therefore most probably contributed significantly to the actual decriminalization of consensual sexual acts between adult men, which followed in 1961. It has also become clear that this process was triggered by a single individual's petition, even though additional details regarding this

53 Paragraph 236, Act no. V of 1878 (Hungarian Penal Code) rendered sexual assault conducted by men against "decent maidens" under the age of 14 punishable with a prison sentence up to five years.

54 Takács, "Disciplining gender and (homo)sexuality."

55 See, for example: Linczényi et al., A szeexuális élet ravarai. 
individual's original submission, identity, and exact motives remain unknown for the time being.

The Health Science Council began to function in 1951 within the Ministry of Health, which had been established a year earlier. ${ }^{56}$ Its tasks included "proposing solutions for the management of theoretical and practical medical work [...] preparing resolutions on the application of new medical procedures and new diagnostic approaches," etc. ${ }^{57}$ In 2015, in one of the several hundred boxes containing HSC-related material in the National Archives of Hungary, we have found the minutes of a HSC Neurology Committee meeting which took place on March 21, 1958, ${ }^{58}$ the presentation of Antal Csorba on "Medical and criminal problems of homosexuality," which was discussed in that meeting, ${ }^{59}$ and an official report summarizing the expert opinion of the Neurology Committee, written by Zoltán Alföldy, the secretary of HSC, to Comrade Rostás, ${ }^{60}$ a high commissioner of the Hungarian Socialist Workers' Party. These documents are significant primary sources. To a certain extent, they reflect social and legal discourses. Thus, by discussing their content, we contribute to an understanding of the arguments, both pro and contra, which shaped the political decision on decriminalization in 1961.

In the HSC meeting of March 21, 1958, which was chaired by Professor Gyula Nyírő, only six psychiatrists took part, including Sándor Fodor, Lilly Hajdu, ${ }^{61}$ Pál Juhász and Pál Fodor. Here, we focus on one item of the agenda about the proposal to modify homosexuality-related criminal clauses. ${ }^{62}$ First, Colonel Antal Csorba, chief neurologist of the Hungarian People's Army, general secretary of the Hungarian Society of Neurologists and Psychiatrists, and member of the Pavlov Neurology Panel, gave a presentation on the medical and criminal problems related to homosexuality.

The relatively long (seven and half pages) text was thematically divided into eight main sections. These sections included a definition of homosexuality, a brief "literature review" on congenital and acquired homosexuality, prevalence estimates, an overview of modern European criminal practices, a detailed description of abolitionist arguments, a description of arguments

56 Sótonyi, "Az Egészségügyi Tudományos Tanács története."

57 Source: 193/1951. (XI.01.) Decree of the Council of Ministers.

58 MNL OL, Jegyzőkönyv.

59 MNL OL, A homoszexualitás néhány orvosi és büntetőjogi problémájáról.

60 MNL OL, Feljegyzés Rostás elvtársnak.

61 In the minutes, she was mentioned by her married name, Mrs. Gimes ("Gimes Miklósné”).

62 MNL OL, Jegyzőkönyv, 1. 
for maintaining criminalization, and possible objections to such arguments, followed by the author's own objections and completed with written proposals for the amendment of the existing law. In general, the proposal seems shaped by the conviction (reflecting and affirming social homophobia) that homosexual acts should be decriminalized not to promote social acceptance, but because the natural aversion deriving from the "healthy heteronormativity" of society is in itself enough punishment for those concerned. Table 1 in the Appendix provides an overview of the pro and contra arguments for (de)criminalization listed in Colonel Csorba's presentation.

Csorba used a broad definition of homosexuality which included not only actual sexual acts but also the contents of sexual dreams, feelings of fondness, sexual attraction, and love. ${ }^{63}$ In the presentation, it was pointed out that it is as difficult for a homosexual individual to initiate heterosexual contact as it is for a heterosexual the other way around. It was also stressed that the case histories of homosexual relationships often include severe mood swings, depressive reactions, suicide attempts, and even violent acts. At the same time, Csorba admitted that "prohibition might also play a role in maintaining a constant psychological tension." ${ }^{94}$ Csorba distinguished between homosexuality and bisexuality, defining the latter as "two-way sexuality," when in addition to the main heterosexual interest, occasional homosexual episodes might occur, typically under the influence of alcohol. ${ }^{65}$

The two-page "literature review" drew attention to the distinctions drawn in textbooks among forms of congenital and acquired homosexuality, as well as bisexuality. In the context of acquired forms of homosexuality, Csorba referred to Freudianism and to Alfred Binet's and Konrad Lorenz's approaches, especially in relation to the early stages of instinctual life, when imprinting might play an important role in human sexual development: "it is often the case that memory material reveals the decisive influence of first experiences." ${ }^{966}$ Here, Csorba also mentioned the possibility of seduction by adult homosexuals, briefly reporting two unusual examples from his "own material" of a homosexual father who influenced his child's sexual development. In other cases, he added, it is not about "rough seduction", but fine involvement and the feeling of sympathy developed in the family (or a familiar) environment that can affect the direction

63 MNL OL, A homoszexualitás néhány orvosi és büntetőjogi problémájáról, 1.

64 Ibid.

65 Ibid.

66 Ibid. 2. 
of sexual interest. ${ }^{67}$ However, he emphasized, new studies seriously challenged the idea of "genetic predetermination," and he brought up the Turner-syndrome as an example, where "external feminine genitalia are possible with a male chromosome set without the person psychosexually identifying as a man: this person identifies as a woman as she was raised, thus psychosexuality does not seem to be dependent on the sex chromosome" (it is worth noting that this is a complete misunderstanding of what Turner-syndrome, in which a female is partly or completely missing an X chromosome, actually is).$^{68}$ When highlighting the potential weaknesses regarding the biological-genetic determination of homosexuality, he questioned the validity of Theo Lang's theory, reviving Richard Goldschmidt's association of homosexuality with intersexuality, ${ }^{69}$ by quoting upto-date medical findings. These findings included an article in The Lancet about the Chromosomal Sex in Transvestites, published by Canadian medical professors in 1954, pointing out that male transvestites have male chromosomes, refuting the contrary "working hypothesis" of Danish professor, Christian Hamburger; ${ }^{70}$ and another article published by a Swiss psychiatrist and a German geneticist in 1956, challenging the direct link between chromosomal sex and psychosexual development. ${ }^{71}$ Csorba's conclusion reflected the conviction that the etiology of homosexuality cannot be reduced to either a congenital or an acquired condition or state: the "innate" form can also result from specific environmental effects, he pointed out at the end, but even in this case, sexual direction would be completed for the most part in early childhood. ${ }^{72}$

Regarding the prevalence of homosexuality, Csorba indicated that, based on police records, only a small proportion of the true prevalence can be revealed, and it was impossible to gather accurate statistical data because of the socially concealed nature of homosexual relations. ${ }^{73}$ Yet, in this part he included estimates of Hirschfeld and Kinsey with prevalence figures between 2 percent and 50 percent. Csorba stressed that prevalence data, if it could be collected, would be important for two main reasons. First, "the more common the anomaly, the

\footnotetext{
67 Ibid.

68 Ibid.

69 It should also be noted that "Lang's selection of homosexuality as a problem for genetic research was part of a deliberate effort to win a high place in the National Socialist hierarchy." Dietrich, "Of Moths and Men," 241.

70 Barr and Hobbs, "Chromosomal Sex in Transvestites," 1110.

71 Bleuler and Wiedemann, "Chromosomengeschlecht und Psychosexualität."

72 MNL OL, A homoszexualitás néhány orvosi és büntetőjogi problémájáról, 2-3.

73 Ibid., 3.
} 
more desirable it is to withdraw penalization." 74 Second, with the accessibility of reliable statistics, by comparing results from countries where homosexual acts are criminalized and countries where homosexuality is not criminalized, it would be possible to test whether criminalization can be a practical solution at all.

The overview of the modern European criminal practices stressed, as a potential example to be avoided, that "in Hitler's Germany, [homosexuality] was persecuted with severe penalties but without any particular success." Regarding the Soviet Union, the text emphatically stated that "the 1927 Soviet Criminal Code did not punish [homosexuality]," while it would have been enough to communicate only the second half of the sentence, where it turns out that, later, homosexuality became a prohibited act punishable "in accordance with subsequent amendments." ${ }^{\prime 75}$ It was then pointed out that, as in the rest of Europe, in other state-socialist People's Republics there was no unified position on the criminalization of homosexual acts (here it was erroneously indicated that the Romanian Penal Code of 1948 prohibited homosexual acts only in the case of public scandal and that in Yugoslavia homosexuality has not been criminalized), adding that "the Austrian Criminal Code is the only one that recognizes and at the same time criminalizes female homosexuality." 76

In the next paragraphs, some of the representatives of the abolitionists were introduced, including the German lawyer and self-declared homosexual, Karl Heinrich Ulrichs, who had fought by legal means against the criminalization of homosexuality already in the 1860s, as mentioned earlier. Here, Csorba referred to the fact that, since the era in which Ulrichs had been waging his campaign, countless articles, submissions, and proposals had been prepared by homosexual persons demanding the abolition of criminalization, and he added that "this was a still ongoing process, since one such submission gave the opportunity to compile the present work, too." ${ }^{\prime 77}$ This sentence clearly indicates that the issue of decriminalization was pushed on the Health Science Council's agenda by a homosexual individual's official submission, and since only male homosexuality was criminalized in Hungary, it can be safely assumed that this individual was a man.

It should be noted that the legal overview part did not contain any reference to the 1957 Wolfenden Report, which was compiled by a more diversified

\footnotetext{
74 Ibid.

75 Ibid., 4.

76 Ibid.

77 Ibid.
} 
committee than the Hungarian one, including officials, churchmen, lawyers, scientists, and psychiatrists, even though its conclusions largely corresponded to the main points presented by Csorba. ${ }^{78}$ This could be explained by Csorba's medical background or his focus on other state-socialist countries. It is also possible that Csorba was unaware of the report, which helped to facilitate the decriminalization of homosexuality in the United Kingdom, or he may have been familiar with it but may have decided not to quote it for some reason.

After the remarkable revelation about the Health Science Council's agendasetting having been triggered by a homosexual man, Csorba listed the detailed abolitionist arguments, arranged in ten points, followed by the arguments and counterarguments for maintaining criminalization. Table 1 (in the Appendix) gives an overview of these three types of arguments, which are raised in various parts of the text and which we can group according to the thematic categories below.

1. Biological phenomenon and social threat: the prosecution of biological phenomena by law is not logical. However, punishment is necessary to protect the purity of the sex life. At the same time, the purity of society's sex life will not be damaged if homosexual acts are not penalized. A healthy society with heterosexual preferences has a natural aversion to this disorder. Thus, it is not necessary to have a separate penalty. Homosexuality leads to revulsion and disgust, and it does not tempt imitation, and if homosexual acts are not committed in public, there is no question of any social threat.

2. Lack of objective proof and seduction: the offence cannot be proven objectively. However, it is prohibited because it can corrupt the youth by diverting their sexual development in an abnormal direction. At the same time, in the context of heterosexual relations, protection of the youth is covered by other articles in the criminal law, which can be supplemented with regards to homosexuality.

3. Victimless crime and the protection of family life: an offence which has no victim does not pose any danger either to individual rights or to the interests of society. There is no social harm if the acts are committed by consenting adults and not in public. However, these acts can ruin family life. At the same time, penalization cannot guarantee the protection of family life. "Innate" homosexuals are unable to lead a regular heterosexual family life. Among nonheterosexuals, only bisexuals can perhaps lead regular heterosexual family lives.

78 Borgos, "Homosexuality and psychiatry," 929. 
In this context, penalizing extramarital sexual relations would not be logical, since having an extramarital heterosexual relation is not considered a criminal offence either.

4. Population growth: the defendants do not feel guilty. They see their conduct as natural, and their homosexual acts are only repulsive to heterosexuals. However, these acts inhibit population growth. At the same time, the interest of protecting population growth cannot justify penalization, because in this case contraception should be penalized, too.

5. Doubtful treatment outcomes: punishment has no deterrent effect, nor does it have corrective or educational effects, because it cannot affect a deepseated biological disorder. On the other hand, it is well known that imprisonment facilitates homosexual inclinations by providing an exclusively same-sex environment for a longer term. However, at least treatment could be provided for the duration of the prison term. At the same time, prisons or prison hospitals are not suitable environments for the treatment of homosexual disorders. Also, this disorder can be treated successfully only rarely (only in the case of bisexual persons who wish to free themselves from homosexual tendencies).

6. Blackmailing: penalization can be the basis of criminal blackmail. However, lack of penalization would not stop blackmailing activities altogether, since public contempt also makes blackmails possible. At the same time, though lack of penalization would not eradicate blackmail completely, it could significantly reduce its probability.

7. Homosexual marriage: the goal of protecting population growth cannot justify penalization, because in this case, contraception should be penalized, too. However, if we acknowledge the legitimacy of homosexuality, homosexual marriage should also be allowed. At the same time, the marriage of homosexual persons as an act attracting public attention and lacking essential instrumental features that constitute the institution of marriage is certainly undesirable (the need for authorizing same-sex marriage does not follow from the lack of penalizing homosexual acts).

8. Relative prevalence and violation of public tastes: the relative prevalence of homosexuality suggests that punishment should be limited. However, public opinion is for penalization. At the same time, the enlightened and educated public does not demand penalization. The situation of homosexuals is quite tragic even without penalization, because even if the law would not penalize this instinctual anomaly, homosexuals would have to continue to hide, because 
homosexuality would remain a violation of public taste, not to mention the fact that homosexuals are deprived of having offspring, etc.

9. Inconsistency, lack of reliable data, and the negligibility of the risk of "psychological contagion": it is not consistent that homosexuality only be penalized in cases involving men, while it occurs among women in the same way. However, lack of penalization implies permissiveness that can lead to rampant proliferation. At the same time, the risk of rampant proliferation should be assessed only in a statistically reliable way, but unfortunately, there are no comparable datasets available. In the absence of reliable data, the only thing one can say is that in adulthood, the direction of sexual orientation is permanently fixed, and homosexual impulses would affect the normally oriented not in an attractive but in a repulsive way, thus the risk of psychological contagion seems negligible.

10. Sexual needs: all adult individuals have the right to satisfy their sexual needs, even if the mode of satisfaction is irregular. Thus, homosexuality cannot be rendered a crime given that it does not violate individual or collective interests. However, penalization can limit the frequency of the acts, even if it cannot eradicate the inclination. At the same time, the struggle between the dread of being reported, exposed, and punished and the enhanced instinctual drives almost inevitably leads to the exhaustion of the nervous system and neurosis. Even the fear of punishment cannot restrain the homosexuals' quest for sexual satisfaction. They feel that the law cannot deprive them of their sexuality. Thus, the notion that punishment would limit the frequency of homosexual acts is highly unconvincing.

Looking through the list of thematic categories emerging from the text, while there were a few references to psycho-medically relevant content, such as the limited risk of "psychological contagion," doubtful treatment outcomes, and the danger of neurosis, most points were connected to social institutions, concepts, and practices, such as (heterosexual and homosexual) marriage, family, population growth, youth protection, public opinion, avoiding extortion, etc. Additionally, certain legal and methodological problems were also raised by referring to the absence of victims (in the case of victimless crime), lacking consistency regarding the gender of the prosecuted, as well as the lack of objective proof and reliable data concerning the prevalence of homosexuality among the general population. We can also observe that the text was dominated by the arguments concerning decriminalization, which were often rooted in social rather than medical considerations. Consequently, it is not surprising that 
the proposal concluded that a resolution against criminalization seems "(more) appropriate and fair." ${ }^{39}$

At the end of the text, the author presented two proposals regarding how to modify the current text of the law: according to the first option, sexual acts by same-sex partners, whether men or women, should be punishable only if they constitute an assault on or violation of public decency (i.e., if they cause public scandal) or if one of the two participants is younger than 18. According to the second option, zoophilia (or bestiality) should remain punishable, but an equal age of consent of 16 should be introduced for both heterosexual and homosexual relations. Finally, Csorba referred to negative therapeutic experiences and expressed his complete rejection of the potentials of coercive treatment.

Csorba's submission on March 21, 1958 was followed by a brief discussion during which one committee member suggested that the content which had been presented should be published in the Neurology Review, a Hungarian scientific journal. However, this suggestion was rejected by the chair of the committee: in Professor Nyírő's view it would not be advisable to give too much publicity to this issue. He and Pál Juhász agreed about the acquired nature of homosexuality (according to the minutes "based on three observed cases of cure, he [Nyíró] does not consider homosexuality either incurable nor innate" ${ }^{\text {"80 }}$ ), and thus suggested to increase the age of consent to 20 for "(youth) protection purposes." ${ }^{81}$ Lilly Hajdu, ${ }^{82}$ the only female committee member, disagreed with this proposal, arguing that "setting the protected age limit at 20 years is excessive, especially in the case of women whose sexual maturity is completed by the end of puberty." ${ }^{83}$ The discussion ended with the general consensus that the law should be amended according to Colonel Csorba's first proposal, which set the age of consent for same-sex relations at 20 (six years higher than for heterosexuals). Some of Csorba's language and arguments did, in fact, reappear in the 1961 Penal Code.

On July 11, 1958, Zoltán Alföldy, the Health Science Council's secretary, sent only this amendment proposal (together with the list of arguments and

79 MNL OL, A homoszexualitás néhány orvosi és büntetőjogi problémájáról, 4.

80 MNL OL, Jegyzőkönyv, 1.

81 MNL OL, Jegyzőkönyv, 2.

82 We should note that Lilly Hajdu, a significant Hungarian psychoanalyst in the pre-war years and director of the Institute of Psychiatry and Neurology in the mid-1950s, was one of the main initiators of the modernization and humanization of psychiatric methods in Hungarian mental health institutions from the late 1950s onwards. See: Borgos, "Homosexuality and psychiatry," 929.

83 MNL OL, Jegyzőkönyv, 2. 
counterarguments for decriminalization, shown in columns B and C of Table 1) to Comrade Rostás, who most probably conveyed the neurologists' expert opinion to the party leadership. The arguments discussed by the HSC Neurology Committee appeared again only in a slightly modified form on December 16, 1961, during the parliamentary discussion of the draft of the new Penal Code, leading to the decriminalization of consensual homosexual acts between adults, implemented on July 1, 1962.

\section{Conclusion}

One of the ways of tracing socio-historically changing perceptions of homosexuality is to examine the criminal laws in a country. Since criminal law is supposed to prohibit or constrain the violation of widely accepted codified norms with the support and the power of the state, the criminalization of certain forms of transgressive behavior can indicate the importance attached to certain norms, in our case, to heteronormativity, in a society. Analysis of the principles, considerations, and official explanations underpinning the criminalization of sexual relations between same-gender (male) partners reveals that, around the mid-twentieth century, medicalizing references were used in legal and societal judgments concerning same-sex intimacy in Hungary (and elsewhere).

In the present study, we wanted to offer examples of the medicalization process of social issues that otherwise seem difficult to address (i.e., in this case, these issues were put within a psycho-medical ambit) by focusing on a twentiethcentury historical example from Hungary. However, when analyzing the sources, we also identified psycho-medical arguments often interwoven into social arguments. Our investigations revealed that models of homosexuality which pathologized it as a disease and which had been present since at least the end of the nineteenth century exerted an influence on changes to the criminalizing approach to homosexuality in the late 1950s in Hungary. Thus, we can probably state that pathologization brought a certain degree of liberation (at least in a legal sense), while we must also acknowledge that "the 1961 (Hungarian) decriminalization and the 1973 (international) depathologization of homosexuality did not change the pathologizing-normative discursive framework deployed by experts." ${ }^{\text {" }}$

One of the most well-known critics of the pathologization of homosexuality and, in particular, the role played by psychiatrists in this process was American

84 Borgos, "Homosexuality and psychiatry," 936. 
psychiatrist Thomas Szasz. In his 1961 book The Myth of Mental Illness he touched on ideas which bear affinities with Michel Foucault's views on how "madness forged a relationship with moral and social guilt." 85 Szasz argued that, by developing and popularizing the concept of mental illness, psychiatrists tried to monopolize functions of moral control over society that had previously been practiced by religious institutions. ${ }^{86}$ The moral supervision function of psychiatry is especially salient in the ways in which psychiatry contributed to keeping homosexual practices criminalized and pathologized for many decades by providing "scientific" arguments concerning the alleged social harmfulness of homosexuality. ${ }^{87}$

This approach can be applied only with some limitations to the Hungarian state-socialist context, where both religious institutions and psy-sciences were repressed to a certain degree. However, as was the case in other societies characterized by a strongly antisexual culture, the promotion of compulsive heterosexuality, according to which "natural" sexual practices are somewhat ideal-typically defined as involving genital intercourse and having conception as their main goal, the symbolic significance of homosexual acts could be seen as a real threat ${ }^{88}$ in state-socialist Hungary.

The main focus of Szasz's argument was the role played by psychiatrists in the regulation of personal morality in the name of the public good, a central point also raised by the Wolfenden Report (officially the Report of the Departmental Committee on Homosexual Offences and Prostitution, chaired by Sir John Wolfenden), which was originally published in 1957 in the United Kingdom. This was the most comprehensive legal review of homosexuality-related issues in mid-twentiethcentury Europe. The report also addressed more general questions, such as the connection between crime and sin and the extent to which criminal law should concern itself with the enforcement of morals. By examining the function of

85 Foucault, Mental Illness and Psychology, 69.

86 Szasz, The Myth of Mental Illness.

87 Ibid.

88 Szasz describes this threat in the following way: "Like the political subversive who undermines the value of established political institutions or the religious subversive who undermines the value of established religious institutions, the homosexual undermines the value of heterosexuality. [...] The homosexual thus threatens the heterosexual on his own grounds. He makes the heterosexual fear not only that he too may be homosexual but also that heterosexuality itself is not as much 'fun' as it has been made out to be. Many people behave as if sexual satisfaction were one of their main interests in life. If the value of their favorite game is undermined, they may lose interest in it, and then what will they do?" Szasz, "Legal and Moral Aspects," 135. 
criminal law, the Wolfenden Committee adopted an approach according to which it did not recommend criminalization in regard to matters of personal morality unless they were seen as directly affecting the public good. ${ }^{89}$

As discussed previously, Colonel Csorba's submission neglected to reference the Wolfenden Report when giving an overview of the contemporary European legal landscape. In addition to the possible explanations given above, we can add that even if Csorba was aware of the Wolfenden Report, perhaps he chose not to acknowledge its findings due to their somewhat limited relevance and applicability to state-socialist contexts. On the other hand, we can argue that the Hungarian Neurology Committee's expert opinion contributed to the introduction of legislative change which ceased regulating homosexuality-related personal morality by criminal sanction and limited the scope of legislation to specific issues, including the control of "youth corruption," with the aim of protecting society from what was perceived by the expert committee and the policymakers as acts and conduct with socially harmful consequences.

In a recent study on sexual criminal law liberalization initiated by the international forensic community after World War II, Wannes Dupont challenged the perception of the 1950s as an "era of homophobia and sexual repression" 90 in Western Europe. Thus, we can see the Hungarian Neurology Committee's activities and the following legislative change as coinciding with, and at the same time fitting into, a broader trend and an emerging approach to homosexuality characterized by "a fundamental legal distinction between the private realm of consensual sexual discretion and a public sphere of enforced propriety (effectively understood as heteronormative familialism)." ${ }^{\prime 1}$

The Soviet 1950s were also recently reinterpreted by Rustam Alexander, who explored the "bottom-up movement for decriminalization of sodomy among Soviet leading legal experts and their scholarly arguments."92 By examining archival documents, he noticed that from the late 1950s, several Soviet legal academics

89 According to the report, criminal law's function "is to preserve public order and decency, to protect the citizen from what is offensive or injurious, and to provide sufficient safeguards against exploitation or corruption of others, particularly those who are especially vulnerable because they are young, weak in body or mind or inexperienced, or in a state of special physical, official or economic dependence. [...] It is not, in our view, the function of the law to intervene in the private lives of citizens, or to seek to enforce any particular pattern of behaviour, further than is necessary to carry out the purposes we have outlined." Wolfenden, Wolfenden Report, 23-24.

90 Dupont, "The Two-faced Fifties," 394.

91 Dupont, "The Two-faced Fifties," 358.

92 Alexander, "Soviet Legal," 52. 
kept listing arguments for the abolition of the Soviet anti-sodomy law, but representatives of law-enforcement agencies did not listen to them. This could be explained by the divide between academic and law-enforcement opinions on the criminalization of homosexuality. The main abolitionist arguments included similar ones to those listed in Colonel Csorba's Hungarian text, such as the "biological" nature of homosexuality and difficulties in controlling it because of its intimate nature. However, in a 1973 Russian manual, there was a new argument introduced about the decriminalization of consensual homosexual acts in other state-socialist countries, including Hungary: "the development of criminal legislation over recent years testifies to the gradual departure from criminalization of consensual sodomy, not only in capitalist countries (England and West Germany), but also in socialist countries (East Germany, Hungary, Czechoslovakia, Bulgaria, Poland)." ${ }^{93}$ These new findings can raise the possibility of cross-fertilization of legal approaches from different directions within the (not at all homogeneous) group of state-socialist and Western bloc countries, in the realm of supranational organizations, and among these entities as well.

In conclusion, various forms of pathologizing were reflected in the 1958 arguments of the Hungarian Neurology Committee and in the official reasoning of the 1961 bill presented in the Hungarian Parliament. The fact that the issue of (de)criminalization was discussed and decided by a group of psychiatrist experts can in and of itself reveal the functioning of psycho-medicalization. However, this framework provided support for ending the criminalization of consensual sexual acts conducted by adult men. Moreover, the submission, carefully prepared by Antal Csorba, the chief neurologist of the Hungarian People's Army, was dominated by social rather than medical considerations, and it presented homosexuality as an "anomaly" to which imprisonment was not seen as an effective solution or treatment.

Though we were able to present many pieces of previously unknown information in this study, many questions remain open regarding the timing (i.e., what happened to Colonel Csorba's submission between 1958 and 1961?), the circumstances, and the causes of the 1961 Hungarian decriminalization of homosexuality. As is often the case with original archive research material, we have found some important pieces of the puzzle, but we are far from seeing the whole picture.

93 Alexander, "Soviet Legal," 46. 
Additionally, we cannot state that, on the basis of our insights, the 1958 opinion of the Neurology Committee or the 1961 Penal Code reform could be interpreted as a sign for the more favorable social treatment of homosexuality than previously. As various forms of media and cultural artifacts and commodities from state-socialism reveal ${ }^{94}$ and as participants in documentaries report, ${ }^{95}$ many people who were attracted to members of the same sex continued their mostly closeted life after the 1961 legal reform, and finding partners, for instance, remained difficult for them.

Finally, an unexpected finding of our present study is that the issue of decriminalization may well have been pushed onto the political agenda by a homosexual individual's official submission, and if this was the case, it can be safely assumed that this individual was a man (since only men were affected by criminalization in Hungary). Unfortunately, assuming there was such an individual, additional details regarding his submission and its path to the Neurology Committee remain unknown for the time being, as no relevant archival data could be found regarding these details. However, on the basis of the documents presented here, the assumption that the decriminalization process of consensual homosexual acts leading to the Penal Code reform in 1961 was triggered by a determined, probably gay, abolitionist's activities seems well-founded. Assuming this was the case, this can be considered a unique feature of the history of the decriminalization of homosexuality among the state-socialist countries in the 1950s and perhaps even beyond.

\section{Archival Sources}

Magyar Nemzeti Levéltár Országos Levéltára [Hungarian National Archives] (MNL OL)

XIX-C-8 ETT. A homoszexualitás néhány orvosi és büntetőjogi problémájáról (Csorba Antal aláírásával) [Medical and criminal problems of homosexuality - signed by Antal Csorba]

XIX-C-8 ETTT. Jegyzőkönyv (Nyírő Gyula aláírásával) [Minutes - signed by Gyula Nyíró]

94 See for example Murai and Tóth, "Női szerelmek a filmvásznon."

95 See for example the Hungarian documentaries Secret Years (2009; http://www.uk.eltitkoltevek.hu, accessed April 11, 2021.); Hot Men, Cold Dictatorships (2015; http://www.imdb.com/title/tt4070672/, accessed April 11, 2021). 
XIX-C-8 ETTT. Feljegyzés Rostás elvtársnak (Alföldy Zoltán aláírásával) [Report to Comrade Rostás - signed by Zoltán Alföldy]

Országgyúlési Könyvtár [Library of the Hungarian Parliament]

Országgyúlési irományok [Parliamentary documents] (OGyI)

Az Országgyúlés 1961. december 15-i ülése [Meeting of the Parliament on December 15, 1961] Accessed April 11, 2020. http://library.hungaricana.hu/hu/view/ OGYK_KN-1958_01/

Országos Széchényi Könyvtár Kézirattár [Manuscripts Archive of National Széchényi Library]

Kertbeny, Károly. Levéltöredék: Autobiographiai jegyzetek [Letter sketch: Autobiographical notes], 1868.

\section{Bibliography}

Alexander, Rustam. "Soviet Legal and Criminological Debates on the Decriminalization of Homosexuality (1965-75)." Slavic Review 77, no. 1 (2018): 30-52. doi: 10.1017/ slr.2018.9.

Angyal, Pál. A szemérem elleni büntettek és vétségek [Crimes and offences against sexual morality]. Budapest: Attila Nyomda Részvénytársaság, 1937.

Barr, Murray L, and Edgar G. Hobbs. "Chromosomal Sex in Transvestites." The Lancet, 263, no. 6822 (1954): 1109-10. doi:10.1016/s0140-6736(54)92157-1.

Beachy, Robert. "The German Invention of Homosexuality." The Journal of Modern History 82, no. 4 (2010): 801-38. doi:10.1086/656077.

Bleuler, Manfred, and Hans-Rudolf Wiedemann. "Chromosomengeschlecht und Psychosexualität.” Archiv für Psychiatrie und Nervenkrankheiten, 195, no. 1 (1956), 14 19. doi:10.1007/bf00342002.

Borgos, Anna. "Homosexuality and psychiatry in state-socialist Hungary: Representing women's same-sex desire in the psychomedical literature." American Psychologist 74, no. 8 (2019): 925-39. doi: 10.1037/amp0000560.

Borgos, Anna. Nemek között: Nótörténet, squexualitástörténet [Between genders: History of women, history of sexuality]. Budapest: Noran, 2013.

Davison, Kate. "Cold War Pavlov: Homosexual aversion therapy in the 1960s." History of the Human Sciences 34, no. 1 (2020): 89-119. doi:10.1177/0952695120911593.

Dietrich, Michael R. "Of Moths and Men: Theo Lang and the Persistence of Richard Goldschmidt's Theory of Homosexuality, 1916-1960." History and Philosophy of the Life Sciences, 22, no. 2 (2000): 219-47. 
Dota, Franko. "Javna i politička povijest muške homoseksualnosti u socijalističkoj Hrvatskoj (1945-1989)" [Public and political history of male homosexuality in socialist Croatia, 1945-1989]. PhD diss., Zagreb: Faculty of Humanities and Social Sciences, Department of History, 2017.

Dupont, Wannes. "The Two-faced Fifties: Homosexuality and Penal Policy in the International Forensic Community (1945-1965)." Journal of the History of Sexuality 28, no. 3 (2019): 357-95. doi: 10.7560/JHS28302.

Edvi, Illés Károly. A magyar büntetötörvénykönyv magyarázata [Explanation of the Hungarian Penal Code]. Vol. 2. Budapest: Révai testvérek, 1909.

Eördögh, András. "A büntetőtörvény 241. \-áról [About Section 241 of the Penal Code]." Ügyvédek lapja 38, (1894): 4-6.

Fónagy, Zoltán. "The Age of Dualism." In A Concise History of Hungary, edited by István György Tóth, 425-73. Budapest: Corvina-Osiris, 2005.

Foucault, Michel. The History of Sexuality. Volume 1, An Introduction. London: Penguin Books, 1978.

Foucault, Michel. Mental Illness and Psychology. Berkeley-Los Angeles-London: University of California Press, 2008 [1962].

Freund, Kurt. "Should homosexuality arouse therapeutic concern?" Journal of Homosexuality 2, (1977): 235-40. doi: 10.1300/J082v02n03_06

Healey, Dan. Homosexual Desire in Revolutionary Russia: The Regulation of Sexual and Gender Dissent. Chicago: The University of Chicago Press, 2001. doi:10.7208/ chicago/9780226922546.001.0001.

Healey, Dan. "Homosexual Existence and Existing Socialism: New Light on the Repression of Male Homosexuality in Stalin's Russia." GLQ: A Journal of Lesbian and Gay Studies 8, no. 3 (2002): 349-78. doi:10.1215/10642684-8-3-349.

Herzog, Dagmar. Sexuality in Europe: A Twentieth-Century History. Cambridge: Cambridge University Press, 2011. doi:10.1017/CBO9780511997075

Hildebrandt, Achim. "Routes to decriminalization: A comparative analysis of the legalization of same-sex sexual acts." Sexualities 17, no. 1-2 (2014): 230-53. doi: $10.1177 / 1363460713511105$.

HRW (Human Rights Watch). Public Scandals: Sexual Orientation and Criminal Law in Romania, 1 January 1998. 1-56432-178-9. Accessed May 6, 2020 https://www. refworld.org/docid/3ae6a7e70.html.

Janes, Dominic. "Oscar Wilde, Sodomy, and Mental Illness in Late Victorian England." Journal of the History of Sexuality 23, no. 1 (2014): 79-95. doi: 10.7560/JHS23104.

Kennedy, Hubert. Ulrichs: The Life and Works of Karl Heinrich Ulrichs, Pioneer of the modern gay movement. Boston: Alyson, 1988. 
Kertbeny, Károly. "An Open Letter to the Prussian Minister of Justice" (1869). In We Are Everywhere: A Historical Sourcebook of Gay and Lesbian Politics, edited by Mark Blasius, and Shane Phelan, 67-79. London: Routledge, 1997.

Kirchknopf, Johann Karl. "Ausmaß und Intensität der Verfolgung weiblicher Homosexualität in Wien während der NS-Zeit. Rechtshistorische und quantitative Perspektiven auf Dokumente der Verfolgungsbehörden." Invertito: Jahrbuch für die Geschichte der Homosexualitäten 15, (2013): 75-112.

Kirchknopf, Johann Karl. "I 129 I b) Fornication against nature, this is with persons of the same-sex": The practices of criminal prosecution of male and female homosexuality in Austria in the course of the 20th century. Presentation at the "Sex and Sexuality in East-Central Europe, Past and Present" conference; Budapest: Central European University, October 16-17, 2015.

Kon, Igor S. Sexual Revolution in Russia: From the Age of the Czars to Today. New York: Free Press, 1995.

Kondakov, Alexander. "Rethinking the Sexual Citizenship from Queer and Post-Soviet Perspectives: Queer Urban Spaces and the Right to the Socialist City." Sexualities 22, no. 3 (2019): 401-17. doi: 10.1177/1363460717737770.

Kovai, Melinda. Lélektan és politika: Psұichotudományok a magyarországi államszocializmusban 1945-1970 [Psychology and politics: Psy-sciences in Hungarian state socialism 1945-1970]. Budapest: Károli Gáspár Református Egyetem-L’Harmattan Kiadó, 2016.

Lang, Birgit and Katie Sutton. "The Queer Cases of Psychoanalysis: Rethinking the Scientific Study of Homosexuality, 1890s-1920s." German History 34, no. 3 (2016): 419-44. doi: 10.1093/gerhis/ghw038.

Linczényi, Adorján, Béla Radnai, and György Vikár. A szexuális élet zavarai [Disorders of sex life]. Budapest: Medicina, 1977.

Long, Scott. "Gay and lesbian movements in Eastern Europe: Romania, Hungary, and the Czech Republic." In The global emergence of gay and lesbian politics: National imprints of a worldwide movement, edited by Barry D. Adam, Jan Willem Duyvendak, and André Krouwel, 242-65. Philadelphia: Temple University Press, 1999.

McLellan, Josie. Love in the Time of Communism: Intimacy and Sexuality in the GDR. New York: Cambridge University Press, 2011.

McLellan, Josie. "Glad to Be Gay Behind the Wall: Gay and Lesbian Activism in 1970s East Germany.” History Workshop Journal 74, no. 1 (2012): 105-30. doi: 10.1093/ hwj/dbs017.

Magyar Törvénytár. 1877-1878. évi Törvényczikekele [1877-1878 Articles of law]. Budapest: Franklin Társulat, 1896. 
Moss, Kevin. "The Underground Closet: Political and Sexual Dissidence in Eastern Europe." In Genders 22: Postcommunism and the Body Politic, edited by E. E. Berry, 229-51. New York: New York University Press, 1995.

Murai, András and Eszter Zsófia Tóth. "Női szerelmek a filmvásznon a rendszerváltás előtt és után" [Women's loves on the movie screen before and after the regime change]. In Homofóbia Magyarországon, edited by Judit Takács, 69-79. Budapest: L'Harmattan.

Pauler, Tivadar. Büntetöjogtan [Criminal law]. Vol. 2, Anyagi büntetőjog különös rész̨e. Alaki jog. Pest: Pfeifer Ferdinánd, 1870.

Pine, Lisa. Nazi Family Policy, 1933-1945. Oxford: Berg Publisher, 1997.

Pretsell, Douglas Ogilvy. The Correspondence of Karl Heinrich Ulrichs, 1846-1894. Cham: Palgrave Macmillan, 2020.

Reich, Péter K. "A természet elleni fajtalanság büntethetőségéről” [On the criminality of unnatural fornication]. A jog 24, no. 12 (1905): 89-91.

Seidl, Jan. "Decriminalization of Homosexual Acts in Czechoslovakia in 1961.” In Queer Stories of Europe, edited by Kārlis Vērdinsš and Jānis Ozoliņš̌, 174-94. Newcastle upon Tyne: Cambridge Scholars Publishing, 2016.

Sokolova, Vera. "State approaches to homosexuality and non-heterosexual lives in Czechoslovakia during state-socialism." In The Politics of Gender Culture under State Socialism: An Expropriated Voice, edited by Hana Havelková, and Libora OatesIndruchová, 82-109. London: Routledge, 2014.

Sótonyi, Péter. "Az Egészségügyi Tudományos Tanács története (1863-2009)" [The history of the Health Science Council, 1863-2009]. Egészségtudomány 54, no. 3 (2010): 17-26.

Stella, Francesca. Lesbian Lives in Soviet and post-Soviet Russia. Post/Socialism and Gendered Sexualities. Basingstoke: Palgrave Macmillan, 2015. doi:10.1057/9781137321244

Szasz, Thomas. The Myth of Mental Illness. New York: Hoeber-Harper, 1961.

Szasz, Thomas. "Legal and Moral Aspects of Homosexuality." In Sexual inversion: The multiple roots of homosexuality, edited by Judd Marmor, 124-39. New York: Basic Books, 1965.

Szikra, Dorottya, Cristina Rat, and Tomasz Inglot. Continuity and Change in Family Policies of the New European Democracies: A Comparison of Poland, Hungary and Romania. Part 1, Institutional Legacies and Path Dependence in Family Practice - 1945 to 2000 (NCEEER Working Paper). Seattle, WA: National Council for Eurasian and East European Research, 2011.

Szulc, Lukasz. Transnational Homosexuals in Communist Poland: Cross-Border Flows in Gay and Lesbian Magazines. New York: Palgrave Macmillan, 2017. doi:10.1007/978-3-31958901-5 
Takács, Judit. “The Double Life of Kertbeny.” In Past and Present of Radical Sexual Politics, edited by G. Hekma, 51-62. Amsterdam: UvA-Mosse Foundation, 2004.

Takács, Judit. "Disciplining gender and (homo) sexuality in state socialist Hungary in the 1970s." European Review of History: Revue européenne d'histoire 22, no. 1 (2015): 161-75. doi: 10.1080/13507486.2014.983426.

Takács, Judit, Roman Kuhar, and Tamás P. Tóth. "Unnatural Fornication Cases under State-Socialism: A Hungarian-Slovenian Comparative SocialHistorical Approach." Journal of Homosexuality 64, no. 14 (2017): 1943-60. doi: 10.1080/00918369.2016.1273719.

Tobin, Robert Deam. Peripheral Desires: The German Discovery of Sex. Philadephia, PA: University of Pennsylvania Press, 2015. doi:10.9783/9780812291865

Torra, Michael Jose. "Gay rights after the Iron Curtain." The Fletcher Forum of World Affairs 22, no. 2 (1998): 73-87.

Ulrichs, Karl Heinrich. [1864-79] Forschungen über das Räthsel der Mannmännlichen Liebe. Edited by Hubert Kennedy. 4 vols. Berlin: Verlag Rosa Winkel, 1994.

Wolfenden, John et al. The Wolfenden Report: Report of the Committee on Homosexual Offences and Prostitution. New York: Stein and Day, 1963 [1957].

\section{Appendix}

Table 1. Pros and cons of decriminalizing homosexual acts in Hungary (1958)

\begin{tabular}{|c|c|c|}
\hline $\begin{array}{l}\text { A) Abolitionist } \\
\text { arguments for } \\
\text { decriminalization }\end{array}$ & $\begin{array}{l}\text { B) Arguments } \\
\text { to maintain } \\
\text { criminalization }\end{array}$ & $\begin{array}{l}\text { C) Arguments against maintenance } \\
\text { of criminalization }\end{array}$ \\
\hline $\begin{array}{l}\text { 1. The prosecution of } \\
\text { biological phenomena by } \\
\text { law is not logical }{ }^{1}[\ldots]\end{array}$ & $\begin{array}{l}\text { BUT punishment is } \\
\text { necessary to protect } \\
\text { the purity of sex life. }{ }^{2}\end{array}$ & $\begin{array}{l}\text { AT THE SAME TIME the purity of society's sex } \\
\text { life will not be damaged, if [homosexual acts are] } \\
\text { not penalized. A healthy society with heterosexual } \\
\text { preferences has a natural aversion to this disorder, it } \\
\text { does not appear necessary to have a separate penalty. } \\
\text { [Homosexuality] leads to revulsion and disgust, and } \\
\text { it does not tempt imitation, and if homosexual acts } \\
\text { are not committed in public, there is no question of } \\
\text { any social threat. }^{3}\end{array}$ \\
\hline $\begin{array}{l}\text { 2. The offence cannot be } \\
\text { proven objectively }{ }^{4}[\ldots]\end{array}$ & $\begin{array}{l}\text { BUT it is punishable, } \\
\text { because it can } \\
\text { corrupt the youth by } \\
\text { diverting their sexual } \\
\text { development in an } \\
\text { abnormal direction. }^{5}\end{array}$ & $\begin{array}{l}\text { AT THE SAME TIME, in the context of } \\
\text { heterosexual relations, protection of the youth is } \\
\text { covered by other articles of the criminal law, which } \\
\text { can be supplemented with regard to homosexuality. }\end{array}$ \\
\hline
\end{tabular}




\begin{tabular}{|c|c|c|}
\hline $\begin{array}{l}\text { A) Abolitionist } \\
\text { arguments for } \\
\text { decriminalization }\end{array}$ & $\begin{array}{l}\text { B) Arguments } \\
\text { to maintain } \\
\text { criminalization }\end{array}$ & $\begin{array}{c}\text { C) Arguments against maintenance } \\
\text { of criminalization }\end{array}$ \\
\hline $\begin{array}{l}\text { 3. An offence which } \\
\text { has no victim does not } \\
\text { pose any danger either } \\
\text { to individual rights or to } \\
\text { the interests of society. } \\
\text { There is no social harm } \\
\text { if the acts are committed } \\
\text { by consenting adults and } \\
\text { not in public }{ }^{7}[\ldots]\end{array}$ & $\begin{array}{l}\text { BUT it can ruin } \\
\text { family life. }\end{array}$ & $\begin{array}{l}\text { AT THE SAME TIME, penalization cannot } \\
\text { guarantee protection of family life. "Inborn" } \\
\text { homosexuals are unable to lead regular heterosexual } \\
\text { family life. This [heterosexual family life] can be } \\
\text { observed in the cases of bisexuality. In this context, } \\
\text { penalizing extramarital sexual relations would not be } \\
\text { logical since extramarital heterosexual relations are } \\
\text { not considered a criminal offence either." }\end{array}$ \\
\hline $\begin{array}{l}\text { 4. The defendants do } \\
\text { not feel guilty. They see } \\
\text { their conduct as natural, } \\
\text { and their (homosexual) } \\
\text { acts are only repulsive to } \\
\text { heterosexuals }{ }^{10}[\ldots]\end{array}$ & $\begin{array}{l}\text { BUT [these acts] } \\
\text { inhibit population } \\
\text { growth. }{ }^{11}\end{array}$ & $\begin{array}{l}\text { AT THE SAME TIME, the interests of protecting } \\
\text { population growth cannot justify penalization, } \\
\text { because in this case contraception should be } \\
\text { penalized, too. }{ }^{12}\end{array}$ \\
\hline $\begin{array}{l}\text { 5. Punishment has no } \\
\text { deterrent effect, nor } \\
\text { does it have corrective } \\
\text { or educational effects, } \\
\text { because it cannot affect } \\
\text { a deep-seated biological } \\
\text { disorder. On the other } \\
\text { hand, it is well known } \\
\text { that imprisonment } \\
\text { facilitates homosexual } \\
\text { inclinations by providing } \\
\text { a long-term same-sex } \\
\text { environment } t^{13}[\ldots]\end{array}$ & $\begin{array}{l}\text { BUT at least } \\
\text { treatment could be } \\
\text { provided for the } \\
\text { duration of the prison } \\
\text { term. }{ }^{14}\end{array}$ & $\begin{array}{l}\text { AT THE SAME TIME, prisons or prison hospitals } \\
\text { are not suitable environments for the treatment of } \\
\text { homosexual disorders. [...] Also, this disorder can be } \\
\text { treated successfully only rarely ([only] in the case of } \\
\text { bisexual persons who wish to free themselves from } \\
\text { homosexual tendencies). }{ }^{15}\end{array}$ \\
\hline $\begin{array}{l}\text { 6. Penalization can be } \\
\text { the basis of criminal } \\
\text { blackmail }^{16}[\ldots]\end{array}$ & $\begin{array}{l}\text { BUT lack of } \\
\text { penalization would } \\
\text { not stop blackmailing } \\
\text { activities altogether, } \\
\text { since public contempt } \\
\text { also makes blackmails } \\
\text { possible. }\end{array}$ & $\begin{array}{l}\text { AT THE SAME TIME, though lack of penalization } \\
\text { would not eradicate blackmail completely, it could } \\
\text { significantly reduce [its probability]. }{ }^{18}\end{array}$ \\
\hline $\begin{array}{l}\text { 7. The goal of } \\
\text { protecting population } \\
\text { growth cannot justify } \\
\text { penalization, because in } \\
\text { this case, contraception } \\
\text { should be penalized, } \\
\text { too }^{19}[\ldots]\end{array}$ & $\begin{array}{l}\text { BUT if we } \\
\text { acknowledge the } \\
\text { legitimacy of } \\
\text { homosexuality, } \\
\text { homosexual marriage } \\
\text { should also be } \\
\text { allowed. }\end{array}$ & $\begin{array}{l}\text { AT THE SAME TIME, the marriage of } \\
\text { homosexual persons as an act attracting public } \\
\text { attention and lacking essential instrumental features } \\
\text { that constitute the institution of marriage is certainly } \\
\text { undesirable, [but] the need for authorizing [same- } \\
\text { sex marriage] does not follow from the lack of } \\
\text { penalizing [homosexual acts]. }{ }^{21}\end{array}$ \\
\hline
\end{tabular}




\begin{tabular}{|c|c|c|}
\hline $\begin{array}{l}\text { A) Abolitionist } \\
\text { arguments for } \\
\text { decriminalization }\end{array}$ & $\begin{array}{l}\text { B) Arguments } \\
\text { to maintain } \\
\text { criminalization }\end{array}$ & $\begin{array}{c}\text { C) Arguments against maintenance } \\
\text { of criminalization }\end{array}$ \\
\hline $\begin{array}{l}\text { 8. The relative prevalence } \\
\text { of homosexuality } \\
\text { suggests that punishment } \\
\text { should be limited }{ }^{22}[\ldots]\end{array}$ & $\begin{array}{l}\text { BUT public opinion is } \\
\text { for penalization. }\end{array}$ & $\begin{array}{l}\text { AT THE SAME TIME, the enlightened and } \\
\text { educated public does not demand penalization. } \\
\text { The situation of homosexuals is quite tragic even } \\
\text { without penalization, because even if the law would } \\
\text { not penalize this instinctual anomaly, homosexuals } \\
\text { would have to continue to hide, because } \\
\text { homosexuality would remain a violation of public } \\
\text { taste, not to mention the fact that homosexuals are } \\
\text { deprived of having offspring, etc. }{ }^{24}\end{array}$ \\
\hline $\begin{array}{l}\text { 9. It is not consistent } \\
\text { that homosexuality only } \\
\text { be penalized in cases } \\
\text { involving men, while it } \\
\text { occurs among women in } \\
\text { the same way }{ }^{25}[\ldots]\end{array}$ & $\begin{array}{l}\text { BUT lack of } \\
\text { penalization implies } \\
\text { permissiveness that } \\
\text { can lead to rampant } \\
\text { proliferation. }^{26}\end{array}$ & $\begin{array}{l}\text { AT THE SAME TIME, the risk of rampant } \\
\text { proliferation should be assessed only in a statistically } \\
\text { reliable way, but unfortunately, there are no } \\
\text { comparable datasets available. In the absence of } \\
\text { reliable data, the only thing one can say is that in } \\
\text { adulthood, the direction of sexual orientation is } \\
\text { permanently fixed, and homosexual impulses would } \\
\text { affect the normally oriented not in an attractive but } \\
\text { in a repulsive way, thus the risk of psychological } \\
\text { infection seems negligible. }\end{array}$ \\
\hline $\begin{array}{l}\text { 10. All adult individuals } \\
\text { have the right to satisfy } \\
\text { their sexual needs, and } \\
\text { even irregular modes } \\
\text { of satisfaction cannot } \\
\text { render the act a crime } \\
\text { given that it does not } \\
\text { violate individual or } \\
\text { collective interests }^{28}[\ldots]\end{array}$ & $\begin{array}{l}\text { BUT penalization can } \\
\text { limit the frequency } \\
\text { of the acts, even if it } \\
\text { cannot eradicate the } \\
\text { inclination. }^{29}\end{array}$ & $\begin{array}{l}\text { AT THE SAME TIME, the struggle between the } \\
\text { dread of being reported, exposed, and punished } \\
\text { and the enhanced instinctual drives almost } \\
\text { inevitably leads to the exhaustion of the nervous } \\
\text { system and neurosis. Even the fear of punishment } \\
\text { cannot restrain the homosexuals' quest for } \\
\text { sexual satisfaction: they feel that the law cannot } \\
\text { deprive them of their sexuality. Thus, the notion } \\
\text { that punishment would limit the frequency of } \\
\text { homosexual acts is highly unconvincing. }\end{array}$ \\
\hline
\end{tabular}

1 MNL OL, A homoszexualitás néhány orvosi és büntetőjogi problémájáról, 5 .

2 Ibid.

3 Ibid. 6.

4 Ibid. 5.

5 Ibid.

6 Ibid. 6.

7 Ibid. 5 .

8 Ibid.

9 Ibid. 6.

10 Ibid. 5.

11 Ibid.

12 MNL OL, Feljegyzés Rostás elvtársnak, 2.

13 MNL OL, A homoszexualitás néhány orvosi és büntetőjogi problémájáról, 5 .

14 Ibid.
15 Ibid. 6.

16 Ibid. 5.

17 Ibid. 6.

18 Ibid. 7.

19 Ibid. 5.

20 Ibid.

21 Ibid. 6.

22 Ibid. 5.

23 Ibid. 6.

24 Ibid. 7.

25 Ibid. 5.

26 Ibid. 6.

27 Ibid. 7.

28 Ibid. 5.

29 Ibid. 6.

30 Ibid. 7. 